\title{
The roles of herpes simplex virus in neuroscience
}

\author{
Sharon L Turner ${ }^{1}$ and Frank J Jenkins ${ }^{2}$ \\ ${ }^{2}$ Department of Pathology, School of Medicine; ${ }^{2}$ Department of Infectious Diseases and Microbiology, School of Public \\ Health; ${ }^{1,2}$ Division of Behavioral Medicine and Oncology, University of Pittsburgh Cancer Institute; ${ }^{1,2}$ Center for \\ Neuroscience, University of Pittsburgh, Pittsburgh, PA 15213, USA
}

\begin{abstract}
Herpes simplex virus (HSV) has been a focus of research in many laboratories during the last 30-35 years, with the majority centered on the virus' replication, molecular biology and pathogenesis. Recently, HSV has begun to receive considerable attention in the field of neuroscience, where scientists have begun to use the virus as a tool or model for several areas of investigation. These areas include the construction and development of HSV-based vectors for gene therapy and the use of HSV as a neuronal tracer, as a model for demyelinating disease and to study interactions between the nervous, immune and endocrine systems. The goal of this paper is to review these different roles for HSV in the broad field of neuroscience.
\end{abstract}

Keywords: herpes simplex virus; neuroscience; viral vectors; latency; demyelination; neuro-immune interactions

\section{Introduction}

Herpes simplex virus (HSV) refers to two closely related members of the human herpesvirus family; herpes simplex virus type 1 and herpes simplex virus type 2 . HSV-1 and HSV-2 share a significant homology at genetic and nucleic acid levels and can produce similar diseases ranging from inapparent infections and self-limiting cutaneous lesions to fatal encephalitis (for a review, see Whitley and Gnann, 1993). In addition, the virus establishes and maintains a latent state in sensory neurons from which recurrent HSV infections arise.

The properties of HSV that make it a useful tool for studies in the field of neuroscience include its neurotropism, the ability to construct viral mutants that express foreign genes and its ability to establish latent infections in neuronal cells. In this review we will discuss five different roles for HSV in neuroscience which include (1) a model for demyelinating disease, (2) a tool for transneuronal tracing studies, (3) use as a viral vector for gene therapy, (4) a model for studying neuro-immune interactions, and (5) a model for studying health effects of chronic stress. A complete discussion of any of these roles would require its own separate review and is beyond the scope of this review. Instead, we will briefly discuss each role and, in instances where it is possible, point the reader to more detailed reviews on each subject.

Correspondence: FJ Jenkins

Received 31 May 1996; revised 18 November 1996; accepted 5 December 1996

\section{HSV infections}

In a primary infection, HSV enters the body via mucosal membrane or abraded skin and establishes infection locally in epithelial cells. Active viral replication in these cells results in the amplification of virus, the formation of a 'fever blister' and the stimulation of both cellular and humoral immune responses (as reviewed in Hill, 1985). HSV spreads from infected epithelial cells to axons of sensory neurons innervating the site of local infection where it travels by retrograde axonal transport to the neuronal nuclei (Cook and Stevens, 1973). Studies using animal models have indicated that infected neurons demonstrate either a limited viral replication or establish a latent infection (as discussed in Cook and Stevens, 1973; Hill, 1985). While the exact mechanism(s) for the establishment of HSV latency have yet to be determined, recent studies have suggested that the decision between active versus latent infection is made soon after neuronal infection (Simmons et al, 1992; Speck and Simmons, 1992).

HSV latency is characterized by the presence of viral genomes in the nuclei of infected neurons and the absence of viral replication or viral protein production (for review, see Hill, 1985). The infection and establishment of latency within neurons explains why HSV is termed a neurotrophic virus. In a neuron in which the virus is latent, there are no virus-specific proteins produced and thus the host's immune system is unaware of the virus' presence. As a result, the immune system does not target the latently-infected neuron for destruction, and anti- 
body levels to HSV antigens are not continuously stimulated during viral latency.

A latent HSV infection is maintained for the life of the host, but the virus can be reactivated periodically to produce infectious virus and recurrent disease (as reviewed in Hill, 1985). During reactivation, viral replication occurs within the reactivated neuron, producing infectious viral progeny. Mature virions are transported back down the sensory axon where they may establish a recurrent infection in the epithelia of the skin. Studies using both animal models and human subjects have shown that viral reactivation can be triggered by a variety of stressful or stress-related stimuli including heat, UV light, fever, hormonal changes, menses and physical trauma to the neuron (e.g. Segal et al, 1974; Spruance, 1985; Carlton and Kilbourne, 1952; Pazin et al, 1978). While the virus appears to be latent most of the time, HSV infection is probably best characterized by recurrent reactivations and periods of latency.

\section{HSV replication}

The HSV genome is a linear, double-stranded DNA approximately $150 \mathrm{~Kb}$ in length (McGeoch et al, 1988). There are at least 75 separate open reading frames encoded within this DNA genome. Molecular studies have revealed that many of these genes can be deleted without interfering with the virus' ability to replicate in cell culture lines (as reviewed in Ward and Roizman, 1994). In addition, it is possible to construct site-specific mutations, including the deletion of viral genes and the insertion of foreign genes, into the viral genome (for example, Post and Roizman, 1981; Roizman and Jenkins, 1985; Jenkins and Roizman, 1986).

HSV genes are divided into three major temporal classes $(\alpha, \beta$, and $\gamma)$ which are regulated in a coordinated, cascade fashion (for review see Roizman and Sears, 1993). The $\alpha$ or immediate-early (IE) genes contain the major transcriptional regulatory proteins and their production is required for the transcription of the $\beta$ and $\gamma$ gene classes. $\beta$ proteins are not produced in the absence of $\alpha$ proteins and their synthesis is required for viral DNA replication. The $\beta$ proteins consist primarily of proteins involved in viral nucleic acid metabolism. The $\gamma$ proteins reach peak rates of synthesis after the onset of DNA replication and consist primarily of virus structural proteins.

Two HSV- $1 \alpha$ proteins that are relevant for the discussions in this review are called ICP0 and ICP4 (ICP=infected cell protein). ICP4 is the major regulatory protein of HSV and deletion studies have demonstrated that it is absolutely required for viral replication (DeLuca and Schaffer, 1988b; Dixon and Schaffer, 1980; Preston, 1979; DeLuca et al, 1984, 1985). The ICP4 protein is involved in the transactivation of both $\beta$ and $\gamma$ genes (as reviewed in Roizman and Sears, 1993), but may also repress its own transcription and the transcription of other genes containing ICP4 repressor elements (DeLuca and Schaffer, 1988a; Muller, 1985; Watson and Clements, 1980; Kristie and Roizman, 1986). ICP4 deletion mutants must be maintained in cell culture systems which provide the missing ICP4 gene in trans to the virus. The use of the complementing cell lines to propagate ICP4 mutant viruses has further delineated the functions of ICP4 as well as assisted in the development of viral vectors.

Similar to ICP4, another major regulatory protein, ICP0, exhibits more moderate transactivation of the $\beta$ and $\gamma$ class genes (Cai and Schaffer, 1992). Transient expression assays have also suggested that ICP0 is capable of trans-activating ICP4 and is critical for the replication of $\mathrm{HSV}$ following transfection of viral DNA (Cai et al, 1993a; Cai and Schaffer, 1989). While the synthesis of ICP0 is not essential for viral replication in cell culture (Sacks and Schaffer, 1987; Stow and Stow, 1986), it does appear to be involved in viral replication in animal models and in viral reactivation triggered by ganglion explanation (Leib et al, 1989a,b). These properties are best demonstrated in a recent study by Cai et al (1993b) which utilizes nonsense, insertion and deletion mutants of ICP0 to delineate the effects of mutant ICP0 peptides on viral replication and reactivation. Plasmid constructs containing the mutated ICP0 genes (which were used to generate the ICP0 viral mutants) exhibited unique levels of transactivating activity as measured by the ability of the expressed ICP0 peptides to stimulate transcription of ICP0 promoter-responsive genes in vitro. In a murine model for HSV replication and latency, using the ICP0 mutants, it was reported that the efficiency of viral replication in the eyes and trigeminal ganglia of inoculated mice, and the frequency of viral reactivation induced by ganglion explant, correlated with the levels of ICP0 transactivating activity. This data suggests a functional role for ICP0 in viral replication and reactivation in vivo. However, levels of viral DNA as determined by PCR analysis, did not correlate with the efficiency of viral replication or reactivation, suggesting that other, as yet undefined factors, may influence the ability of the virus to establish neuronal latency.

HSV latency is defined by the presence of viral genomes and the absence of viral protein production within infected cells. While this definition suggests that viral gene transcription is absent, a small subset of viral transcripts, termed the latency associated transcripts (LATs) are transcribed during active and latent infections (Wechsler et al, 1988; Wagner et al, 1988; Stevens et al, 1988; Krause et al, 1990; Rock et al, 1987; Roizman and Sears, 1993). The function of the LAT transcripts is unclear. Viral deletion mutants indicate that the LATs are not required to establish latent infection (Ho and Mocarski, 1989; Steiner et al, 1989). In addition, 
contradicting data indicate variable roles for the LATs in viral reactivation. Some studies report decreased reactivation frequencies in LAT mutants whereas others document no difference in reactivation frequencies in LAT mutants and wild type virus (Natarajan et al, 1991; Block et al, 1990; Perng et al, 1996; Maggioncalda et al, 1994). Such inconsistencies may be partially explained by the different mutations in the different LAT mutants which include deletions in LAT promoter sequences and LAT coding sequences. An additional problem arises from the fact that the LAT gene is located antisense to the ICP0 gene (Stevens et al, 1987). The overlap between the LAT and ICP0 genes makes it difficult to ascertain possible functions of LAT since many LAT mutations commonly disrupt ICP0 sequences. As previously discussed, ICP0 plays an important role in viral replication and reactivation in vivo and therefore LAT mutations may not always delineate the functions of LAT from those of ICPO.

A model for virus-induced demyelinating disease Animal studies using peripheral inoculations of HSV on the cornea, snout, footpad or vagina have demonstrated that the virus spreads from peripheral epithelial cells to both the peripheral nervous system (PNS) and central nervous system (CNS; Townsend and Baringer, 1978a,b; Kristensson et al, $1978,1979)$. Cellular damage induced by the virus is markedly different in these two areas. Tissue damage in the PNS is generally mild while the damage in the CNS is often extensive within a local foci. A well studied example of this concept is seen within the trigeminal root entry zone (TREZ) of the brainstem, a junction region between the PNS and CNS (Townsend and Baringer, 1978a,b; Townsend, 1983). Within this region, following an acute HSV infection, the peripheral myelin is untouched while the CNS side of the trigeminal root develops demyelinated lesions. Within the demyelinated lesions, there is an absence of myelin and the presence of both intact axons and a mononuclear cell (MNC) infiltrate. The exact mechanism of demyelination is not known, but results from several studies suggest that it is a combination of cellular infection and host immune response. Townsend and Baringer (1978b) reported that cyclophosphamide injections reduced the amount of both MNC infiltrate and myelin destruction in the CNS following corneal HSV infections. Townsend (1981a) later reported that corneal infections in nude (athymic) mice resulted in an absence of demyelinating lesions. Kristensson et al (1982) demonstrated that the timing of administration of immunosuppressive agents such as cyclophosphamide could either enhance or suppress the immune reaction producing either an increase or decrease in demyelination. Studies comparing genetically distinct strains of mice have identified strains which range in their resistance to
CNS demyelination. Susceptible strains exhibit multifocal demyelination, while moderately resistant strains exhibit unifocal demyelination and resistant strains simply exhibit an increased presence of inflammatory cells at the TREZ (Kastrukoff et al, 1987). This study was followed by a more recent report which described investigations on the effects of immunosuppression on TREZ demyelination in strains of immunocompetent mice, immune deficient mice, and immunocompetent mice that had been immunosuppressed with either cyclosporin A or cyclophosphamide (Kastrukoff et al, 1993). Animals that were immune deficient or immunosuppressed either lacked evidence of demyelination or exhibited reduced levels of demyelination when compared to immunocompetent mice. Taken together, these studies clearly demonstrate that the immune system plays an important role in the development of demyelination during an acute HSV infection and that this response may be influenced by genetic determinants. In addition, it was demonstrated that infectious virus was required for the development of demyelinating lesions and that the presence of virus alone was not sufficient. Townsend (1981b) also reported that following a peripheral HSV infection, the virus spreads from the PNS to the CNS where it initially infects and lyses astrocytes. This infection occurs prior to onset of demyelination. Following the infection of astrocytes, immune cells appear and demyelination begins. The results of this study were later confirmed by Itoyama et al (1991). Thus HSV-induced demyelination of the CNS appears to be due to a combination of viral-induced lysis of astrocytes and oligodendrocytes and immuno-pathology caused by immune cell infiltrates.

A puzzling aspect of HSV-induced demyelination is the development of lesions only within the CNS and not in the PNS. One explanation for this has been a reported inability of Schwann cells to be productively infected with HSV. Electron microscopic studies have reported that following a peripheral HSV infection (such as corneal inoculation) Schwann cells were found to contain viral capsids, but not enveloped particles, suggesting an abortive infection within these cells (Rabin et al, 1968; Hill and Field, 1973). The inability of HSV to productively infect and lyse Schwann cells would prevent the attraction of immune cells and therefore demyelination would not occur. This theory has been supported in a study by Townsend and Collins (1986) in which infection and lysis of Schwann cells and subsequent demyelination of the PNS was achieved only by the direct inoculation of HSV into the sciatic nerve. A productive infection of the Schwann cells was established along with an immune cell infiltrate and subsequent demyelination. These results suggest that during a peripheral HSV infection, there is some sort of block preventing the virus from productively infecting the 
Schwann cells which is overcome by direct inoculation of the nerve.

Several investigators have also reported that following the development of demyelinating lesions, some remyelination of the naked axons occurs. Remyelination was first noted by Kristensson et al (1979). Separate reports by Kristensson et al (1982) and by Townsend (1983) reported that the remyelination appeared to be due to the migration of Schwann cells from the PNS to the CNS. Schwann cell remyelination of CNS axons was later confirmed by Soffer and Martin (1988) using a vaginal infection with HSV-2. In at least one study, there was evidence of multiple episodes of demyelination followed by remyelination (Soffer and Martin, 1988). In instances where HSV establishes latency and cycles through several rounds of reactivation, it is reasonable to postulate that cyclic episodes of demyelination followed by remyelination also occur.

As all of the studies just described demonstrate, HSV infection provides a good model for studies investigating the demyelination of CNS axons through a combination of cellular damage and immunopathology (ie the cytotoxic effects of an immune cell infiltrate). Interestingly, HSV and HSV antibodies have been isolated from patients exhibiting episodes of multiple sclerosis (MS), supporting the relevance of this model to MS-related clinical pathology (Bergstrom et al, 1989). Studies on the mechanisms of CNS demyelination and the longterm effects of demyelination followed by remyelination may serve as an excellent model for trigeminal neuralgia (Burchiel, 1993). In addition, the HSV model may be helpful in studies investigating other human demyelinating diseases such as Bell's palsy and multiple sclerosis (Vahlne et al, 1985).

\section{A tool for transneuronal tracing studies}

Neuroscientists have long desired to map chains of neurons in order to identify communication pathways from origin to termination. With the use of antero- and retrograde tracers such as fast blue and horseradish peroxidase it is possible to identify single neurons along with their axons and terminations. However, to identify synaptically linked second and third order neurons, transneuronal tracers are required.

In order for a transneuronal tracer to be effective it must be specific for synaptically linked connections, possess the ability to be transported antero- or retrogradely and be sufficiently tagged for efficient and sensitive detection. Substances such as cholera toxin, tetanus toxin and wheat germ agglutinin are known to bind specifically at neuronal membranes and have been used as transneuronal tracers (Cabot et al, 1984; Jansen et al, 1993; Hirakawa et al, 1993). These methods have limitations however, since only small amounts of protein are transported across synapses resulting in an absence of or relatively weak labeling of linked neurons. In addition, nonspecific labeling of adjacent neurons can occur at increased injection concentrations and extended labeling times. Neurotropic viruses, specifically herpesviruses, possess an advantage to these other contemporary methods in that they are able to replicate within neuron cell bodies providing signal amplification before infecting secondand third-order neurons. The herpesviruses have also been shown to specifically label neuronal connections in both the retrograde and anterograde direction (Ugolini et al, 1987; Norgren Jr, et al, 1992).

The most common viral transneuronal tracers are herpes simplex virus 1 and 2 (HSV-1/HSV-2) and pseudorabies virus (PRV). All three viruses belong to the alpha herpesvirinae family and therefore are neurotrophic (Roizman and Sears, 1993). The ability of these DNA viruses to specifically infect neurons contributes to their transneuronal transport. The most common method used to detect the presence of these viruses in neuronal tissue is by immunohistochemical staining for viral antigen. Other methods that can be used include direct labeling of virus particles with $\mathrm{S}^{35}$ (by growth of viral stocks in the presence of $S^{35}$-labeled amino acids) or by incorporation of the $\beta$-galactosidase gene in their DNA genome (Loewy et al, 1991). In the former method, presence of virus is detected by photographic emulsion while in the latter method, tissues are incubated with a chromogenic substrate (such as X-gal) that detects the presence of the $\beta$ galactosidase enzyme.

Viral tracings require certain precautions. In order to correctly interpret viral tracing studies it is important to understand the mechanisms of viral uptake, transport, replication and release as well as the generation of specific immune responses by host immune cells and their associated neuropathology. Careful analyses should identify transneuronal connections by comparison of viral tracing results with conventional transneuronal tracers that are injected concurrently to viral infection. Other important considerations include the presence of alternate innervation pathways which could contribute to nonspecific labeling; for example, nonspecific labeling may result from dissemination of virus from the site of inoculation to adjacent sites. Experiments used to obtain transneuronal tracings are controlled by the strain of virus used, the host animal, the site of injection, the amount of virus inoculated, the time of post-inoculation analysis, and the extent of neuropathology associated with the infection. The importance of these parameters is apparent from many studies which have reported false labeling under conditions of severe gliosis and at late survival times. (Norgren Jr and Lehman, 1989; Strack and Loewy, 1990). However, careful analyses from several transneuronal tracing studies 
HSV in neuroscience

SL Turner and FJ Jenkins which contain proper controls have demonstrated the use of herpes viruses to identify transneuronal connections (for example, Strack et al, 1989; Spencer et al, 1990; Jansen et al, 1992; Loewy et al, 1991; Rotto-Percelay et al, 1992; Schramm et al, 1993; Hedner et al, 1993; Vizzard et al, 1995).

Reports from several studies have identified properties of the herpesviruses that contribute to the specificity of transneuronal labeling. Vahlne and colleagues have studied the attachment and adsorption of HSV-1 and HSV-2 to glial cells, neuronal perikarya and synaptosomal fractions of brain homogenates (Vahlne et al, 1978, 1980). They reported that synaptosomal fractions of brain homogenates exhibited the strongest viral adsorption followed by glial cells and neuronal perikarya. In addition, it was observed that HSV-2 bound less efficiently than HSV-1 in each respective fraction of rat, human or monkey brain preparations. However, HSV-1 and HSV-2 demonstrated equal binding in mouse glial cell preparations. Pseudorabies virus uptake and retrograde transport studies have reported the presence of limited viral specific receptors on axon terminals which mediate viral uptake (Marchand and Schwab, 1986). These findings suggest preferential infectivity at the synapse, but also illustrate that host species type, viral strain and different cell types influence the path of infection.

Electron microscopic studies using HSV and PRV have demonstrated that fusion of the viral envelope with the cellular plasma membrane of neuronal extensions is followed by retrograde axonal transport of unenveloped nucleocapsids along axonal microtubules (Ugoline et al, 1987). Although this is the primary mode of viral transport to the neuronal nucleus, it is not exclusive. Other studies have shown anterograde transport of virus (Norgren Jr, et al, 1992; Card et al, 1990), and at least one report suggests that the direction of transneuronal transport may be strain dependent (Zemanick et al, 1991). By analyzing labeled neurons at progressive timepoints, it has been determined that retrograde transport occurs much faster than anterograde transport (Norgren Jr, et al, 1992). Consideration of the difference in transport rate is important in tracing analyses and can be useful in determining connections between groups of neurons. For example, in groups of neurons which are highly connected by collaterals, one must consider the fact that individual neuron labeling could be due to either antero- or retrograde transport, and in such instances, there may be no way to distinguish between originating and target cells. It is particularly important to consider this limitation when interpreting the specificity of viral tracing studies.

Once delivered to the neuronal cell body, herpes virus nucleocapsids are observed at the pores of nuclear membranes where they release their DNA into the nucleus. The viral replicative cycle consists of virus-specific transcription and translation, viral DNA synthesis, and the assembly of mature nucleocapsids. Viral capsid envelopment and egress are complicated pathways which differ according to viral strain and the type of cell infected. Regardless of the observed differences, two processes seem most important for the production and passage of mature virions. The first involves the acquisition of a bilaminar membrane or transport vesicle which will permit fusion with the plasma membrane and viral egress. Secondly, viral glycoproteins must be processed to their fully functional form by association with the Golgi apparatus or golgi-derived vesicles which contain the enzymes required for these modifications. These processes are necessary to ensure that virions will be released from the cell with the ability to bind via glycoprotein receptors to infect adjacent cells.

Our current understanding of the mechanisms by which virions traverse the cell are the result of limited analyses offered by electron microscopy. In HSV infected neurons, nucleocapsids have been observed obtaining a primary envelope at the inner lamina of the nuclear membrane. Virions are subsequently released into the endoplasmic reticulum as naked nucleocapsids by a de-envelopment fusion with the outer nuclear membrane (Marchand and Schwab, 1986; Lycke et al, 1988). HSV nucleocapsids receive a secondary envelopment by the endoplasmic reticulum and follow anterograde transport to the cellular membrane by a transport vesicle. Virus observed in the cytoplasm of dorsal root ganglion (DRG) neurons appear to be contained within these transport vesicles. Fusion of vesicles with the plasma membrane at axonal terminals releases infectious, enveloped virions capable of infecting adjacent cells. Similar replicative processes in neurons of the vagal motor nucleus have been reported in a study by Card and colleagues using pseudorabies virus (PRV; Card et al, 1993). In this study, the authors reported that PRV nucleocapsids obtained a single envelope from the inner nuclear membrane and traversed the inner lamina to gain access to the endoplasmic reticulum (ER). From the ER, virus fused with the outer ER membrane, entering the cytoplasm as naked nucleocapsids which subsequently become enveloped in a bilaminar structure by the trans cisternae of the Golgi. Fusion of the outer virion envelope with synaptic membranes occurred at adjacent terminals, releasing single enveloped virions with surface glycoproteins in the correct orientation to transneuronally fuse.

Although the release of herpes viruses occurs at neuronal terminals, sites of virion egress do not always occur directly into synaptic clefts. Herpescontaining vesicles have been reported to fuse at presynaptic terminals, releasing enveloped virus which fuses to postsynaptic membranes adjacent to presynaptic terminals. This results in the entry of 
naked nucleocapsids into the neuron. Astrocytes are also susceptible to PRV and HSV infection, but infected cells are only observed subsequent to an adjacent neuronal infection. Ultrastructural analyses of PRV-infected astrocytes have revealed a defect in the cytoplasmic envelopment of viral nucleocapsids. This defect renders nucleocapsids incapable of plasma membrane fusion, resulting in an absence of viral egress and an accumulation of virion particles within the cellular cytoplasm (Card et al, 1993). The resulting abortive infection effectively prevents astrocytic PRV virions from contributing to nonspecific extracellular spread. At present, no such mechanisms are known for HSV. In fact, HSV has been reported to be quite capable of establishing a productive infection in astrocytes (Itoyama et al, 1991). The inability of PRV to establish a productive infection in astrocytes provides a great advantage to PRV in ensuring specific transneuronal transport and is a major reason why PRV is considered by many to be the virus of choice for transneuronal tracing studies.

Additional host mechanisms restricting virus spread to non-neuronal cells are provided by the host's immune response to both PRV and HSV infections. Resident microglia, monocytes and macrophages are activated in the nervous system during viral infection and may effectively phagocytose virus and degenerating cellular debris (Rinaman et al, 1993). The importance of these mechanisms is apparent considering the large viral load which may be released from necrotic cells to the extracellular space. T-lymphocytes may also play a role in the delineation of viral spread (Zhao et al, 1995). Factors regulating these mechanisms have yet to be elucidated, but most likely involve immune-mediated cytokine production and the induction of major histocompatibility antigen expression within the nervous system.

\section{A viral vector for gene therapy}

The advances of modern molecular biology and in vivo gene therapy have challenged neuroscientists with the potential prospect of gene manipulation in postmitotic neurons. The ability to alter gene expression in these cells would open the door towards potential therapies for several disorders such as Parkinson's disease, Huntington's disease and amyotrophic lateral sclerosis. Gene therapy using viral-based vectors has received considerable attention and represents a major focus of ongoing research in many laboratories. Viral vectors using several different human viruses such as adenoviruses, retroviruses and herpes viruses are currently being developed. Gene therapy directed towards neuronal cells however, presents unique problems. These problems include the genetic manipulation of post-mitotic (ie., non-dividing) cells, the ability to specifically infect neurons, long-term maintenance of the vector DNA and expression of the target gene within the neuronal cells. Herpesviruses, particularly herpes simplex virus type 1 , have unique characteristics of infection, replication and pathogenesis which make them potentially ideal candidates for the development of viral vectors capable of altering endogenous gene expression or delivery of foreign genes both in vivo and in vitro. The reader is directed to several reviews on these subjects (Glorioso et al, 1994, 1995; Neuwelt et al, 1995; Kwong and Frenkel, 1995).

Herpes viruses have several advantages which lend to their ability to act as neuronal vectors. HSV exists as a large approximately $150 \mathrm{~Kb}$ double stranded DNA virus which has been entirely sequenced and extensively studied (McGeoch et al, 1988). As a result of many years of intense research, a general knowledge exists of which genes and DNA sequences may be deleted and at which sites foreign DNA may be inserted into the DNA genome (as reviewed in Ward and Roizman, 1994). Research has also defined the minimal requirements for viral replication and packaging (as discussed in Kwong and Frenkel, 1995). HSV-based vector strategies rely on the ability of HSV to infect neuronal cells and establish a latent infection.

The two main strategies for HSV-based vectors are genetically-engineered viruses and plasmid derived 'amplicon' vectors. The first strategy involves the construction of recombinant viruses containing deletions in one or more viral genes whose expression is essential for viral replication (for reviews, see Glorioso et al, 1994, 1995). The deletion of genes whose expression is essential for virus replication (for example, ICP4), results in the production of a virus that cannot replicate in normal cells. Replication of these defective viruses requires a cell line that provides the missing gene (or genes) in trans (termed a complementing cell line). Foreign genes can be inserted into these mutated viral genomes with the goal of producing a virus vector that will infect the target cell (ie., neurons), and express the foreign gene without killing the cell. The second strategy involves the use of plasmid derived vectors containing HSV-1 origins of DNA replication and DNA packaging signals which enable multiple copies of the vector genomes to be packaged into helper virus virions (for reviews see Neuwelt et al, 1995; Kwong and Frenkel, 1995). Helper viruses can be either recombinant viruses containing a deletion within an essential viral gene or viruses containing temperature-sensitive mutations that prevent replication at $37^{\circ} \mathrm{C}$ (normal body temperature). In the case of the former, the replication of the helper virus and packaging of the amplicon vector DNA must occur in a cell line capable of complementing the mutations in the helper virus. Plasmid-derived vectors (amplicons) are advantageous because the DNA constructs can be easily manipulated to test 
endogenous, foreign, antisense or promoter gene expression in the target cell. Although the efficiency of delivery of these multiple copy vectors is high, the primary disadvantage of this system is the fluctuating helper virus to amplicon ratio with passage. These fluctuations must be monitored to ensure high amplicon delivery and experimental reproducibility in the absence of wild-type recombinants (Kwong and Frenkel, 1995).

Regardless of the vector system used, two primary goals must be achieved to enable long-term gene expression in neuronal cells. The first goal involves the construct of mutant vectors which themselves are non-cytotoxic to cells. Several studies have noted active expression of foreign genes by HSV vector constructs which subsequently become inactivated (for examples see Kwong and Frenkel, 1995; Johnson et al, 1992, 1994). Reasons for the inactivation of the HSV construct are not apparent, but evidence suggests that it is a result of cytotoxic effects induced by the vector. This problem has been shown in both plasmid derived and recombinant virus vectors alike. Several lines of evidence suggest that viral immediate early (IE) gene expression may induce CPE (Johnson et al, 1992). Two approaches to circumvent this include HSV vectors with multiple IE gene deletions and vectors with deletions in both IE genes and the HSV VP16 gene. VP16 is a structural HSV protein responsible for transactivating the HSV IE genes (as reviewed in Roizman and Sears, 1993). It has been reported that a HSV mutant containing deletions in two of the five HSV IE genes, namely ICP4 and ICP27, fails to express early and late viral proteins and is less cytotoxic than the parent virus (Glorioso et al, 1994, 1995). Also, it has been reported that a virus lacking VP16 and ICP4 exhibits reduced CPE when compared to an ICP4 deletion mutant (Glorioso et al, 1995). HSV expresses a virion host shut-off (VHS) protein which is responsible for degrading host cell RNA during an active viral replication cycle (Read and Frenkel, 1983). This protein may also be involved in cytopathic effects although a recent study reported no reduction in CPE using vectors containing mutations in the VHS gene (Johnson et al, 1994). Other packaging alternatives may also be explored as ways to deliver HSV vectors that are incapable of establishing a lytic infection. One such method involves the use of L particles, which are defective HSV virions lacking viral DNA, yet are capable of entering cells without causing host cell damage (Glorioso et al, 1994; Rixon et al, 1992).

The second goal in the development of HSV vectors capable of long-term gene expression involves designing stable, active promoters capable of expressing appropriate levels of the foreign protein. The specific promoter involved in individual therapies may change according to the type, status, and activity of the neuronal cell of interest.
Originally, strong promoter systems such as the human cytomegalovirus IE promoter and the Rous sarcoma virus long terminal repeat (RSV LTR) along with several HSV promoters were used to drive gene expression. Although such promoter systems were capable of expression they were only active transiently in the CNS and did not result in longterm gene expression (as reviewed in Glorioso et al, 1995). Neuronal specific promoters (such as the neurofilament and neuronal-specific enolase promoters) which are believed to be constitutively active in neurons, also produced only transient expression in the CNS (Andersen et al, 1993).

A second approach to achieving long term expression in the CNS has been to use the LAT promoters. As mentioned earlier, during HSV latency the only viral transcripts consistently detected are the latency associated transcripts (LATs). The possibility that the LATs are constitutively expressed in latently infected neurons has made them strong candidates for long-term gene expression in neuronal systems. Two latency active promoter (LAP) regions upstream of the LAT transcripts have been identified, termed LAP1 and LAP2 (Dobson et al, 1989; Goins et al, 1994). Transient expression assays and construction of specific deletion mutants have suggested that the LAP1 promoter is the major latency promoter. Deletion of this promoter results in the production of a virus that can establish latency but does not express LAT transcripts (Dobson et al, 1989; Nicosia et al, 1993). The role of LAP2 is less clear, but appears to be required for full expression of the LAT transcripts (Glorioso et al, 1995). The use of LAT promoters for gene expression has met with mixed success. LAP1 constructs have failed to produce long term expression in the CNS (Margolis et al, 1993; Lokensgard et al, 1994), but have been reported to demonstrate reasonable expression in the PNS (Dobson et al, 1989; Wolfe et al, 1992). Glorioso and coworkers have reported that a HSV construct containing a lac $\mathrm{Z}$ gene under the control of the LAP2 promoter is expressed in the brain for at least $41 \mathrm{~h}$ following inoculation (Glorioso et al, 1995). Thus, while short term expression in either the CNS or PNS appears achievable, long term expression in the CNS is still not a definite reality and more research is required to produce an acceptable HSV vector.

\section{A model for studying interactions among the nervous, immune and endocrine systems}

In immunocompetent hosts, active herpes simplex virus infections rapidly stimulate immune responses which function to restrict viral replication and the spread of virus. In addition, the host's immune response is most likely involved in the establishment of latent infections. In fact, the establishment of latency could be viewed as a double-edged sword. It provides the host with a 
mechanism to limit viral spread and cellular damage which, at the same time, ensures the persistence and survival of the virus. In HSVinfected neonates and immunocompromised hosts, virus replicates to high titers, is often widely disseminated and the resulting viral pathology generally extensive. While the mechanisms involved in controlling HSV replication and establishment of latency are not completely understood, it has become increasingly evident that they involve interactions among nervous, immune and endocrine systems. The strongest evidence for these interactions is seen in the establishment of HSV latency.

As mentioned earlier, several studies have suggested that within neurons, the decision to establish either latency or active viral replication occurs very soon after infection (Simmons et al, 1992; Speck and Simmons, 1992). This is indicated by the identification of at least three distinct populations of neurons in infected ganglia. These populations include neurons that express HSV antigens but not LAT, neurons that express LAT but not HSV antigens, and a small proportion of neurons that coexpress LAT and HSV antigens (Simmons et al, 1992; Speck and Simmons, 1992). It is reasoned that neurons which express HSV antigens and no LAT represent active infections while those that express LAT and no antigen represent latent infections. Early divergence (to active replication or latency) is further supported by the realization that lytic replication commits the cell to viral control and cell death as discussed below.

The infection of cells by HSV rapidly results in cell death. Consequences of HSV infection include the disruption of polyribosomes, inhibition and shut-off of host macromolecular synthesis and margination of nuclear chromatin (for review see Roizman and Furlong, 1974). The establishment of a latent HSV infection requires that the infected neuron must survive infection. In order to prevent cell death by HSV, viral replication must be stopped relatively early in its replication cycle. Once the infected cell is committed to viral DNA replication, it is targeted for death. Therefore, to establish a latent infection, the HSV replicative cycle must be stopped prior to $\beta$ protein synthesis. Inhibition at the level of $\alpha$ gene transcription would achieve this goal. The establishment and maintenance of HSV latency therefore, may be due to either the absence of specific cellular transcriptional regulatory proteins that are involved in the positive induction of HSV $\alpha$ genes or to the presence of cellular proteins that repress the specific transcription of the $\alpha$ genes.

At the molecular level, the HSV $\alpha$ genes are unique with regard to the other HSV genes in that their promoter DNA sequences contain one or more copies of the octomer DNA sequence motif TAATGARAT ( $\mathrm{R}=$ =Adenine or Guanine; Mackem and Roizman (1982); Kristie and Roizman (1984). In a lytic viral replicative cycle, this DNA motif is bound by a cellular protein termed Oct-1 (Gerster and Roeder, 1988; Kristie and Roizman, 1987; O’Hare and Goding, 1988). The Oct-1 DNA complex is then bound by a viral protein called the alpha transinducing factor ( $\alpha \mathrm{TIF}$ ) or VP16 (Gerster and Roeder, 1988; McKnight et al, 1987; O’Hare et al, 1988; Preston et al, 1988). The $\alpha$ TIF protein is contained within infectious HSV viral particles and is therefore introduced into the cell upon viral infection. The binding of $\alpha$ TIF to the Oct-1/DNA complex results in a transactivation of the HSV alpha gene promoters and is responsible for the rapid induction of the HSV alpha genes immediately following infection. Since the complex between $\alpha \mathrm{TIF}$ and Oct- 1 is required for the transcription of the $\alpha$ genes, the Oct-1 protein represents a positive cellular transcriptional factor used in the regulation of HSV genes. The cellular Oct-1 protein belongs to a family of proteins that are capable of binding to DNA sequences containing octomer motifs such as TAATGARAT.

Several laboratories have reported that HSV replication is restricted in the mouse neuroblastoma cell line C1300 (Vahlne and Lycke, 1978; Kemp and Latchman, 1989) and in neuronal cell lines derived from dorsal root ganglia (Wheatley et al, 1990). The restriction of viral replication within these cells occurs at the level of HSV $\alpha$ gene expression and appears to be due to the presence of a cellular repressor that binds to the TAATGARAT motif (Kemp and Latchman, 1989; Werstuck et al, 1990). Lillycrop et al (1991) defined the cellular repressor as a neuronal homolog to the Oct-2 transcriptional factor. Oct- 2 is related to Oct- 1 and has been shown to be capable of binding to the TAATGARAT sequence (Gerster and Roeder, 1988). Presumably Oct-2 repression occurs as a result of binding (without the $\alpha$ TIF protein) to the TAATGARAT sequence in $\alpha$ promoters. They also demonstrated that this Oct-2 protein was expressed in dorsal root ganglion neurons. Increasing the levels of Oct- 2 in the neuron cultures by transfecting a plasmid containing the Oct-2 gene decreased the amount of HSV $\alpha$ gene transcription in these cells. It is important to note that Oct-2 was originally defined as a transcriptional activator of genes in B cells (Singh et al, 1986; Staudt et al, 1986) and had not been attributed with any repressor activity. More recent results have demonstrated that differential splicing results in the formation of different isoforms of the Oct-2 protein (Wirth et al, 1991), and the predominant form in lymphocytes is distinct from the predominant form found in neurons (Lillycrop and Latchman, 1992). In transient expression assays the lymphocyte form was reported to act as a positive transactivator of HSV IE promoters while the neuronal form was found to be a repressor of IE transcription (Lillycrop and Latchman, 1992). In addition, Wood and co-workers (Wood et al, 1992) reported that NGF could 
HSV in neuroscience

SL Turner and FJ Jenkins

upregulate (three- to fourfold) the level of Oct-2 in neuronal cultures from dorsal root ganglia. NGF had no effect on the levels of Oct-1 or a neuronalspecific transcriptional factor Brn-3. These results suggested that NGF could mediate the transcriptional effects of Oct-2 in neurons.

Studies using nerve transection or nerve organ cultures have found that the NGF levels in nonneuronal cells increase following nerve injury (Heumann, 1987; Heumann et al, 1987a,b). This increase in NGF was due, at least in part, to the presence of activated macrophages that were responding to the site of injury, and this macrophage-induced increase in NGF was subsequently found to be due to the secretion of the cytokine IL1 (Lindholm et al, 1987). Using cultured explants of sciatic nerves, the addition of cultured medium from activated macrophages or of IL-1 resulted in a 14-fold increase in NGF mRNA (Lindholm et al, 1987). This increase was transient and in order to maintain the higher levels of NGF mRNA, the IL-1 had to be replenished. This increase was not totally IL-1 specific since the addition of tumor necrosis factor (TNF) or platelet-derived growth factor resulted in a doubling of the NGF mRNA levels. However, the addition of prostaglandin E2 or fibroblast growth factor did not result in any mRNA induction. In a subsequent study, Lindholm and co-workers reported that the mechanism of the IL-1-induced increase in NGF was an increase in the stability of the NGF mRNA (Lindholm et al, 1988).

Other evidence further supports a role for NGF in the maintenance of neuronal latency. Wilcox et al (1990); Wilcox and Johnson (1988); Wilcox and Johnson Jr (1987), describe an in vitro model system in which latency is established in cultured sympathetic and dorsal root ganglion neurons. This system relies upon the addition of NGF in addition to antiviral drugs to establish latency. In this system, removal of NGF disrupts latency, lytic gene transcription resumes and viral reactivation occurs. This model suggests that NGF is required for the maintenance of neuronal latency since its removal results in viral reactivation. Later studies have shown that the mechanism of NGF dependent latency involves binding of NGF to the NGF receptor (TrkA) and the stimulation of second messenger pathways (Smith et al, 1992). It has also been found that interruption of RNA transcription or protein synthesis in these latently-infected cells results in viral reactivation with similar kinetics to NGF withdrawal. These data suggest the presence of a neuronal factor, regulated by NGF receptor binding, which contributes to the maintenance of the latent state. The similarities between this in vitro system and the in vivo condition have yet to be determined

Based on the studies described in this section, we have postulated a molecular model for the establish- ment of HSV latency which is dependent on interactions between immune cells, the endocrine system and cells of the PNS (Jenkins and Baum, 1995, Figure 1). During an active HSV infection virus replicates peripherally and is transported to the nuclei of the sensory ganglia innervating the site of infection. Viral replication occurs both at the peripheral site and in some neurons, resulting in an immune response characterized by the attraction of activated macrophages, at both the peripheral site and within the sensory ganglia. The activated macrophages produce a local increase in IL-1 and TNF which in turn results in an increase of NGF. The additional NGF is taken up by the neurons creating an increase in the Oct-2 transcriptional factor. This increase acts to suppress $\mathrm{HSV} \alpha$ gene transcription, leading to the establishment of latency. Levels of Oct-2 would increase in neighboring neurons as well, including both infected and uninfected cells. Neurons in which viral replication had proceeded beyond viral DNA replication, and which express viral proteins, would most likely be targeted for destruction either through viral-induced lysis or immune-mediated cytolysis. Under these conditions, latency would occur in those neurons which contained viral DNA but had yet to initiate viral replication (ie expressing LAT but not HSV antigens). Thus the IL-1/NGF/Oct-2 mediated resistance to HSV transcription is somewhat analogous to viral resistance mediated by the interferons. That is to say that peripheral replication of HSV may induce a non-permissive environment for viral replication in neurons innervating the site of replication. Animal models using corneal infections, have demonstrated that infectious HSV is not detected within trigeminal ganglia until 48-72 h post-infection (Coen et al, 1989; Jenkins and Martin, 1990; Tenser and Edris, 1987). This delay would allow for the establishment of a IL-1/NGF/Oct-2mediated non-permissive environment. This model is based on studies performed in vitro using either established cell culture lines or primary cell lines. It will be important to determine if this model is correct for the establishment of HSV latency in vivo using well-established animal models.

\section{A model for studying health consequences of psychological stress}

In addition to the establishment and maintence of a latent infection, herpesvirus infections are also characterized by recurrent infections that are caused by stress or stress-related reactivations from the latent state. Scientists in the fields of neuroscience and behavioral medicine have long desired to understand the mechanisms by which psychological processes affect biological function. The reactivation of herpesviruses provides an excellent model for studying the direct relationship between biobehavioral processes and disease. 

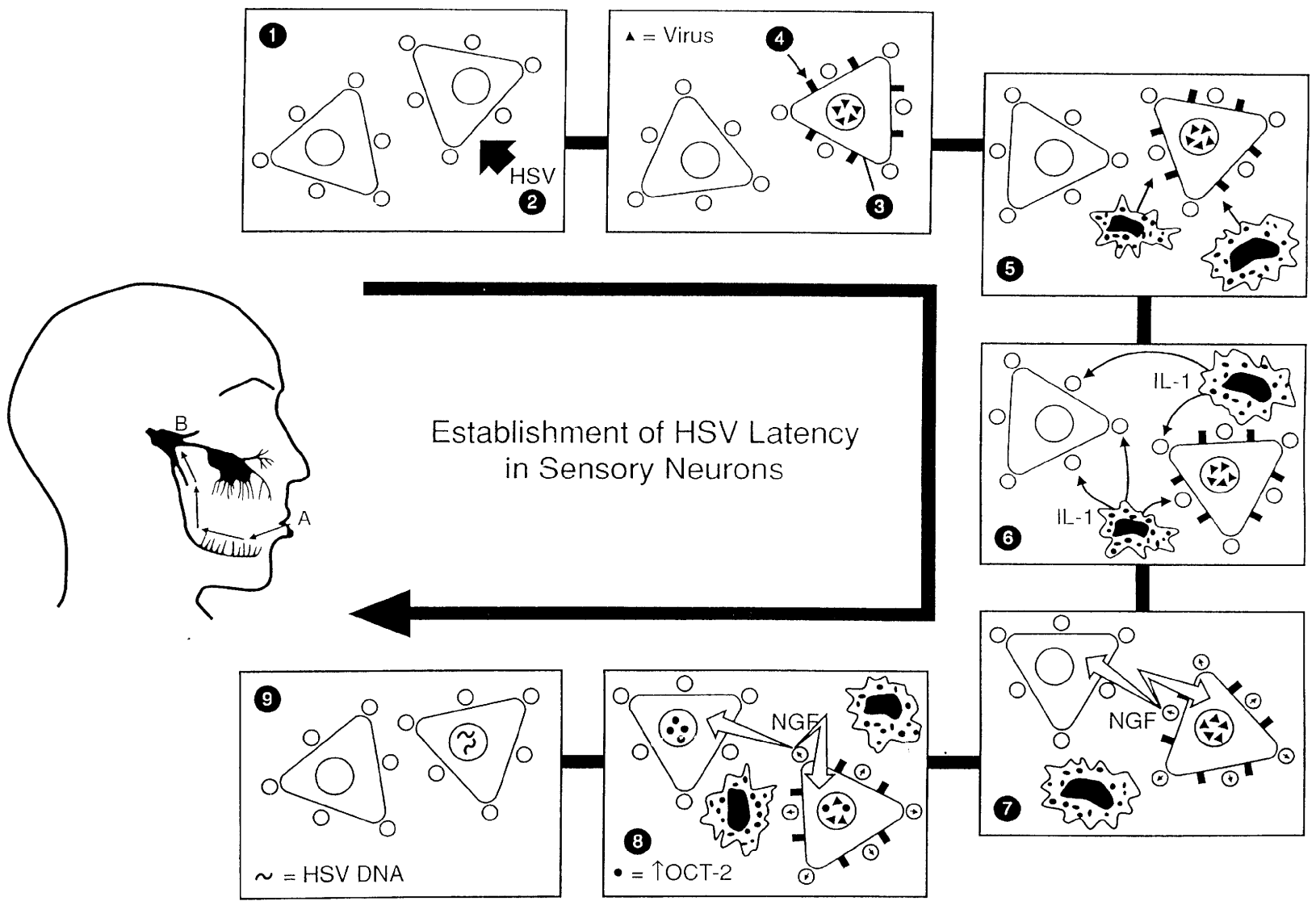

Figure 1 Model for the establishment of HSV latency in sensory neurons. Sensory neurons are depicted as large triangular cells with a circular nucleus. Surrounding the neurons are smaller satellite cells shown as small circles. A primary HSV infection occurs at a peripheral site producing a 'fever blister' (A). The virus is transported to the nuclei of sensory ganglia by retrograde transport along axonal fibers (B). (1) and (2) represent un-infected and infected neurons respectively, surrounded by satellite cells. Virus replication occurs in some of the neurons (3) resulting in the insertion of viral proteins on the surface of the neuron (4). Macrophages are attracted to these neurons (5) where they become activated and begin producing IL-1 (6). The IL-1 causes an increase in the levels of NGF produced by the satellite cells which is taken up by the neurons (7). Increased levels of NGF in the neuron result in an increase in the levels of Oct-2 (8) which results in an inhibition of viral transcription resulting in the establishment of latency (9). Reprinted with permission from Jenkins and Baum, 1995.

Studies in behavioral medicine have demonstrated the ability of psychological stress to induce viral reactivation. Several studies from the Glaser's laboratories at Ohio State University have demonstrated that antibody titers to latent herpesviruses, particularly Epstein-Barr virus (EBV) are elevated in subjects who have been chronically stressed as compared to non-stressed control groups (KiecoltGlaser and Glaser, 1986; Kiecolt-Glaser et al, 1991; Glaser et al, 1985; Kiecolt-Glaser et al, 1987). In one example, stress associated with exam-taking in first year medical students resulted in significant increases in EBV antibody titers (Glaser et al, 1994). In addition, the modulation of EBV antibody levels has been used to define effective coping strategies in psychotherapy patients (Esterling et al, 1994). These types of studies suggest that the observed increases in viral antibody titers is due to reactivation of latent virus which acts to trigger the immune response. A similar type of study has also demon- strated an increase in HSV antibody levels in chronically-stressed individuals. McKinnon et al (1989) reported that individuals living within a three mile radius of the Three Mile Island nuclear plant in Middletown, Pennsylvania demonstrated higher antibody titers to HSV than did control subjects living in Fredrick, Maryland. This increase is specific for HSV and not due to a nonspecific polyclonal B cell activation since antibody titers to Rubella virus did not differ between groups. In addition, increases in HSV antibody titers were not correlated to a concurrent increase in the presence of HSV lesions (A Baum, personal communication) suggesting that viral reactivation resulted in either asymptomatic shedding or an abortive reactivation. It is unlikely that these increases occur in individuals who regularly reactivate HSV, since their antibody levels would be extremely high at baseline. The notion of an abortive reactivation that results in increases in HSV antibody titers without 
viral shedding or recurrent disease is particularly intriguing. In these instances, antibody levels could be used as a marker for stress-induced reactivation in individuals who do not routinely present with recurrent HSV infections. Since a majority of individuals in the general population are felt to have latent HSV in their sensory ganglia while only a small percentage actually demonstrate recurrent disease (as reviewed in Whitley and Gnann, 1993), titers to HSV antibodies may serve as a useful marker for stress-induced abortive reactivations in most people.

The investigation of the role(s) of psychological or physical stress in reactivation of latent herpesviruses needs an appropriate animal model. While animal models for the establishment of herpes latency exist, useful models for reactivation are lacking. Existing in vivo animal models usually reactivate at low frequencies and require stimuli that are often difficult to associate with human phenomena. Animal models for HSV latency include both mouse and rabbit models in which peripheral inoculation with wild-type HSV (eg. on scarified corneas or in footpads) results in the establishment of latency in neurons of the sensory ganglia inervating the site of inoculation (such as the trigeminal or dorsal root ganglia). The most common method for reactivation of latent HSV (from sensory ganglia) is the explanation of latently-infected tissue into cell culture medium (Devi-Rao et al, 1994; Tanaka et al, 1994; Cai et al, 1993b). Following explant, infectious virus can be detected in these tissues 1-5 days later. Some studies have utilized this method to evaluate viral mutants and different strains for reactivation competency in efforts designed to identify viral genes that are involved in reactivation (for example, see Cai et al, 1993b). This procedure, although highly efficient at reactivation (generally $80-95 \%$ effective), represents an in vitro method which should not be interpreted as an in vivo reactivation protocol, even though it results in the reactivation of virus from latently-infected host tissue.

Reactivation procedures representing in vivo protocols include epinephrine-iontophoresis in rabbits, intravenous administration of cyclophosphamide and dexamethasone, corneal scarification, ultraviolet light exposure, surgical trauma, administration of cadmium sulfate, and hyperthermia (Sawtell and Thompson, 1992; Fawl and Roizman, 1993; Harbour et al, 1983; Blyth et al, 1976; Bloom et al, 1994). Most of these suffer from the criticism that they do not have an analogous use in humans. Ideally, what is needed is a reactivation protocol that is based on a psychological stressor and results in significant levels of viral reactivation. However, at the present time, such a protocol does not exist. The major stumbling block may be the simple fact that HSV is a human pathogen which doesn't behave identically in non-human animal models.
The most common endpoint for detecting viral reactivation has been the isolation of infectious virus from either ganglia or tissues. Although this is a fairly sensitive method, it fails to detect abortive replication and therefore may not detect a large percentage of reactivation events. In order to further define distinct reactivation triggers, analyses utilizing methods such as immunohistochemistry, in situ hybridization and RNA PCR may be necessary.

Another reactivation approach involves modulation of the host immune response. When mice are preimmunized with HSV specific antibodies latency is established in the absence of observable pathology and the hosts immune system remains naive to viral antigen (Birmanns et al, 1993). Subsequent exposure to reactivation stimuli leads to reactivation as identified by virus recovery and increased antibody titers. This preimmunization protocol results in increased reactivation percentages as compared to non-immunized mice (Birmanns et al, 1993). Although direct mechanisms for this phenomena have yet to be elucidated, increased levels of viral DNA were observed in ganglia of preimmunized mice. It should be considered that this facilitation of reactivation may be a function of increased detectability due to an unprimed immune response, and not altered triggering stimuli or a prevention of reactivation by an active component of the immune response. With this in mind, the importance of effective and sensitive measures of reactivation becomes apparent.

Stress and its effects on the body and on different systems in the body have recently become more thoroughly defined in biological respects. Key factors, including the hypothalamic-pituitary-adrenal axis and glucocorticoid and catecholamine regulation, have been shown to affect the nervous, endocrine and immune systems (for reviews, see Besedovsky and Del Rey, 1991; Dunn, 1989; Black, 1994; Blalock, 1989). A combined goal of behavioral scientists, neuroscientists and herpes virologists should be to define these responses with respect to viral reactivation. In addition, systemic responses to psychological stressors need to be defined locally at the site of viral latency and reactivation. These goals will only be met using multi-disciplinary approaches and collaborations.

\section{Conclusions}

Herpes simplex virus, as a result of its rather unique life cycle in humans, is a useful tool for many areas of research. Its use in the field of neuroscience represents the newest and certainly one of the most interesting and complex directions of research. Studies utilizing HSV in gene therapy, neuronal tracings, demyelinating diseases, neuro-immune interactions and health related effects of psychological stress will continue for many years and should provide important insights in areas that up to now have been most difficult to study. 


\section{References}

Anderson JK, Frim DM, Isacson O, Breakefield XO (1993). Herpesvirus-mediated gene delivery into the rat brain: Specificity and efficiency of the neuronspecific enolase promoter. Cell Mol Neurobiol 13: $503-515$.

Bergstrom T, Andersen O, Vahlne A (1989). Isolation of herpes simplex virus type 1 during first attack of multiple sclerosis. Ann Neurol 26: 283-285.

Besedovsky HO, Del Rey A (1991). Physiological implications of the immune-neuro-endocrine network. In: Ader R, Felten DL, Cohen H (eds) Psychoneuroimmunology. Academic Press: San Diego, pp 589-608.

Birmanns B, Reibstein I, Steiner I (1993). Characterization of an in vivo reactivation model of herpes simplex virus from mice trigeminal ganglia. $J$ Gen Virol 74: 2487-2491.

Black PH (1994). Immune system-central nervous system interactions: effect and immunomodulatory consequences of immune system mediators on the brain. Antimicrob Agents. Chemother 38: 7-12.

Blalock JE (1989). A molecular basis for bidirectional communication between the immune and neuroendocrine systems. Phsysiological Reviews 69: $1-32$.

Block TM, Spivack JG, Steiner I, Deshmane S, McIntosh MT, Lirette RP, Fraser NW (1990). A herpes simplex virus type 1 latency-associated transcript mutant reactivates with normal kinetics from latent infection. J Virol 64: 3417-3426.

Bloom DC, Devi-Rao GB, Hill JM, Stevens JG, Wagner EK (1994). Molecular analysis of herpes simplex virus type 1 during epinephrine-induced reactivation of latently infected rabbits in vivo. J Virol 68: 12831292.

Blyth WA, Hill TJ, Field HJ, Harbour DA (1976). Reactivation of herpes simplex virus infection by ultraviolet light and possible involvement of prostaglandins. J Gen Virol 33: $547-550$.

Burchiel KJ (1993). Trigeminal neuropathic pain. Acta Neurochirurgica - Supplementum 58: 145-149.

Cabot J, Mennone A, Bogan N, Carroll J, Evinger C, Erichsen JT (1984). Retrograde, trans-promoters. Proc Natl Acad Sci (USA) 81: 4065-4069.

Cai W, Astor TL, Liptak LM, Cho C, Coen DM, Schaffer PA (1993a). The herpes simplex virus type 1 regulatory protein ICP0 enhances virus replication during acute infection and reactivation from latency. $J$ Virol 67: 7501-7512.

Cai W, Astor TL, Liptak LM, Cho C, Coen DM, Schaffer PA (1993b). The herpes simplex virus type 1 regulatory protein ICP0 enhances virus replication during acute infection and reactivation from latency. $J$ Virol 67: 7501-7512.

Cai W, Schaffer PA (1989). Herpes simplex virus type 1 ICP0 plays a critical role in the de novo synthesis of infectious virus following transfection of viral DNA. $J$ Virol 63: 4579-4589.

Cai W, Schaffer PA (1992). Herpes simplex virus type 1 ICP0 regulates expression of immediate-early, early, and late genes in productively infected cells. J Virol 66: $2904-2915$.
Card JP, Rinaman L, Schwaber JS, Miselis RR, Whealy ME, Robbins AK, Enquist LW (1990). Neurotropic properties of pseudorabies virus: uptake and transneuronal passage in the rat central nervous system. J Neurosci 10: 1974-1994.

Card JP, Rinaman L, Lynn RB, Lee BH, Meade RP, Miselis RR, Enquist LW (1993). Pseudorabies virus infection of the rat central nervous system: ultrastructural characterization of viral replication, transport, and pathogenesis. J Neurosci 13: 25152539.

Carlton CA, Kilbourne ED (1952). Activation of latent herpes simplex virus by trigeminal sensory-root section. $N$ Engl J Med 246: 172.

Coen DM, Kosz-Vnenchak M, Jacobson JG, Leib DA, Bogard CL, Schaffer PA, Tyler KL, Knipe DM (1989). Thymidine kinase-negative herpes simplex virus mutants establish latency in mouse trigeminal ganglia but do not reactivate. Proc Natl Acad Sci USA 86: $4736-4740$.

Cook ML, Stevens JG (1973). Pathogenesis of herpetic neuritis and ganglionitis in mice: evidence of intraaxonal transport of infection. Infect Immun 7: 272288.

DeLuca NA, Courtney MA, Schaffer PA (1984). Temperature-sensitive mutants in herpes simplex virus type 1 ICP4 permissive for early gene expression. J Virol 52: 767-776.

DeLuca NA, McCarthy AM, Schaffer PA (1985). Isolation and characterization of deletion mutants of herpes simplex virus type 1 in the gene encoding immediateearly regulatory protein ICP4. J Virol 56: 558-570.

DeLuca NA, Schaffer PA (1988a). Physical and functional domains of the herpes simplex virus transcriptional regulatory protein ICP4. J Virol 62: $732-743$.

DeLuca NA, Schaffer PA (1988b). Physical and functional domains of the herpes simplex virus transcriptional regulatory protein ICP4. J Virol 62: $732-743$.

Devi-Rao GB, Bloom DC, Stevens JG, Wagner EK (1994). Herpes simplex virus type 1 DNA replication and gene expression during explant-induced reactivation of latently infected murine sensory ganglia. J Virol 68: $1271-1282$.

Dixon RAF, Schaffer PA (1980). Fine-structure mapping and functional mapping analysis of temperaturesensitive mutants in the gene encoding the herpes simplex virus type 1 immediate early protein VP175. J Virol 36: 189-203.

Dobson AT, Sederati F, Devi-Rao G, Flanagan WM, Farrell MJ, Stevens JG, Wagner EK, Feldman LT (1989). Identification of the latency-associated transcript promoter by expression of rabbit betaglobin mRNA in mouse sensory nerve ganglia latently infected with a recombinant herpes simplex virus. I Virol 63: $3844-3851$.

Dunn AJ (1989). Psychoneuroimmunology for the psychoneuroendocrinologist: A review of animal studies of nervous system-immune system interactions. Psychoneuroendocrinology 14: 251-274. 
Esterling BA, Antoni MH, Fletcher MA, Margulies S, Schneiderman N (1994). Emotional disclosure through writing or speaking modulates latent Epstein-Barr virus antibody titers. $J$ Consult Clin Psychol 62: $130-140$.

Fawl RL, Roizman B (1993). Induction of reactivation of herpes simplex virus in murine sensory ganglia in vivo by cadmium. J Virol 67: 7025-7031.

Gerster T, Roeder RG (1988). A herpesvirus transactivating protein interacts with transcription factor OTF-1 and other cellular proteins. Proc Natl Acad Sci (USA) 85: $6347-6351$.

Glaser R, Kiecolt-Glaser JK, Speicher CE, Holliday JE (1985). Stress, loneliness, and changes in herpesvirus latency. I Behav Med 8: 249-260.

Glaser R, Pearl DK, Kiecolt-Glaser JK, Malarkey WB (1994). Plasma cortisol levels and reactivation of latent Epstein-Barr virus in response to examination stress. Psychoneuroendocrinology 19: 765-772.

Glorioso JC, Goins WF, Meaney CA, Fink DJ, DeLuca NA (1994). Gene transfer to brain using herpes simplex virus vectors. Ann Neurol 35 Suppl: S28-34.

Glorioso JC, DeLuca NA, Fink DJ (1995). Development and application of herpes simplex virus vectors for human gene therapy. Ann Rev Micro 49: 675-710.

Goins WF, Sternberg LR, Croen KD, Krause PR, Hendricks RL, Fink DJ, Straus SE, Levine $M$, Glorioso JC (1994). A novel latency-active promoter is contained within the herpes simplex virus type 1 UL flanking repeats. J Virol 68: 2239-2252.

Harbour DA, Hill TJ, Blyth WA (1983). Recurrent herpes simplex in the mouse: Inflammation in the skin and activation of virus in the ganglia following peripheral stimulation. J Gen Virol 64: 1491-1498.

Hedner E, Vahlne A, Bergstrom T, Hirsch JM (1993). Recrudescence of herpes simplex virus type 1 in latently infected rats after trauma to oral tissues. $J$ Oral Pathol Med 22: 214-220.

Heumann R (1987). Regulation of the synthesis of nerve growth factor. J Exp Biol 132: 133-150.

Heumann R, Korsching S, Bandtlow C, Thoenen $\mathrm{H}$ (1987a). Changes of nerve growth factor synthesis in non-neuronal cells in response to sciatic nerve transection. I Cell Biol 104: 1623-1631.

Heumann R, Londholm D, Bandtlow C, Meyer M, Radeke MJ, Misko TP, Shooter E, Thoenen H (1987b). Differential regulation of mRNA encoding nerve growth factor and its receptor in rat sciatic nerve during development, degeneration, and regeneration: role of macrophages. Proc Natl Acad Sci (USA) 84: $8735-8739$

Hill TJ (1985). Herpes simplex virus latency. In: Roizman B (ed) The herpesviruses Plenum Press: New York, pp 175 .

Hill TJ, Field HJ (1973). The interaction of herpes simplex virus with cultures of peripheral nervous tissue: An electron microscopic study. J Gen Virol 21: $123-133$.

Hirakawa N, Morimoto M, Totoki T (1993). Sympathetic innervation of the young canine heart using anteroand retrograde axonal tracer methods. Brain Res Bull 31: $673-680$.

Ho DY, Mocarski ES (1989). Herpes simplex virus latent RNA (LAT) is not required for latent infection in the mouse. Proc Natl Acad Sci (USA) 86: 7596-7600.
Itoyama Y, Sekizawa T, Openshaw H, Kogure K, Goto I (1991). Early loss of astrocytes in herpes simplex virus-induced central nervous system demyelination. Ann Neurol 29: 285-292.

Jansen AS, Ter Horst GJ, Mettenleiter TC, Loewy AD (1992). CNS cell groups projecting to the submandibular parasympathetic preganglionic neurons in the rat: a retrograde transneuronal viral cell body labeling study. Brain Res 572: 253-260.

Jansen AS, Farwell DG, Loewy AD (1993). Specificity of pseudorabies virus as a retrograde marker of sympathetic preganglionic neurons: implications for transneuronal labeling studies. Brain Res 617: 103112.

Jenkins FJ, Baum A (1995). Stress and reactivation of latent herpes simplex virus: A fusion of behavioral medicine and molecular biology. Ann Behavioral Med 17: $116-123$.

Jenkins FJ, Martin J (1990). Role of the herpes simplex virus 1 internal repeat sequences in pathogenicity. Intervirology 31: 128-138.

Jenkins FJ, Roizman B (1986). Site-specific mutagenesis of large DNA viral genomes. Bioessays 5: 244-247.

Johnson PA, Miyanohara A, Levine F, Cahill T, Friedmann $\mathrm{T}$ (1992). Cytotoxicity of a replicationdefective mutant of herpes simplex virus type 1. J Virol 66: 2952-2965.

Johnson PA, Wang MJ, Friedmann T (1994). Improved cell survival by the reduction of immediate-early gene expression in replication-defective mutants of herpes simplex virus type 1 but not by mutation of the virion host shutoff function. J Virol 68: 6347-6362.

Kastrukoff LF, Lau AS, Kim SU (1987). Multifocal CNS demyelination following peripheral inoculation with herpes simplex virus type 1. Ann Neurol 22: 52-59.

Kastrukoff LF, Lau AS, Leung GY, Thomas EE (1993). Contrasting effects of immunosuppression on herpes simplex virus type I (HSV I) induced central nervous system (CNS) demyelination in mice. J Neurol Sci 117: $148-158$

Kemp LM, Latchman DS (1989). Regulated transcription of herpes simplex virus immediate-early genes in neuroblastoma cells. Virology 171: 607-610.

Kiecolt-Glaser JK, Fisher LD, Ogrocki P, Stout JC, Speicher CE, Glaser R (1987). Marital quality, marital disruption, and immune function. Psychosom Med 49: $13-34$.

Kiecolt-Glaser JK, Dura JR, Speicher CE, Trask OJ, Glaser $R$ (1991). Spousal caregivers of demintia victims: longitudinal changes in immunity and health. Psychosom Med 53: $345-362$.

Kiecolt-Glaser JK, Glaser R (1986). Psychological influences on immunity. Psychosomatics 27: 621624.

Krause PR, Croen KD, Ostrove JM, Straus SE (1990). Structural and kinetic analyses of herpes simplex virus type 1 latency-associated transcripts in human trigeminal ganglia and in cell culture. J Clin Invest 86: $235-241$.

Kristensson K, Vahlne A, Persson LA, Lycke E (1978). Neural spread of herpes simplex virus type 1 and 2 in mice after corneal or subcutaneous (footpad) inoculation. J Neurol Sci 35: 331-340. 
Kristensson K, Svennerholm B, Persson L, Vahlne A, Lycke E (1979). Latent herpes simplex virus trigeminal ganglionic infection in mice and demyelination in the central nervous system. $J$ Neurol Sci 43: 253-263.

Kristensson K, Svennerholm B, Vahlne A, Nilheden E, Persson L, Lycke E (1982). Virus-induced demyelination in herpes simplex virus-infected mice. I Neurol Sci 53: 205-216.

Kristie TM, Roizman B (1984). Separation of sequences defining basal expression from those conferring $\alpha$ gene recognition with the regulatory domains of herpes simplex virus $1 \propto$ promoters. Proc Natl Acad Sci (USA) 81: 4065-4069.

Kristie TM, Roizman B (1986). DNA-binding site of major regulatory protein $\alpha 4$ specifically associated with the promoter-regulatory domains of $\alpha$ genes of herpes simplex virus type 1. Proc Natl Acad Sci (USA) 83: $4700-4704$.

Kristie TM, Roizman B (1987). Host cell proteins bind to the cis-acting site required for virion-mediated induction of herpes simplex virus $1 \propto$ genes. Proc Natl Acad Sci (USA) 84: 71-75.

Kwong AD, Frenkel N (1995). Biology of herpes simplex virus (HSV) defective viruses and development of the amplicon system. In: Viral Vectors. Anonymous (ed). Academic Press, Inc: pp 25-42.

Leib DA, Bogard CL, Kosz-Vnenchak M, Hicks A, Cohen DM, Knipe DM, Tyler KL, Schaffer PA (1989a). A deletion mutant of the latency-associated transcript of herpes simplex virus type 1 reactivates from the latent state with reduced frequency. J Virol 63: 2893-2900.

Leib DA, Coen DM, Bogard CL, Hicks KA, Yager DR, Knipe DM, Tyler KL, Schaffer PA (1989b). Immediateearly regulatory gene mutants define different stages in the establishment and reactivation of herpes simplex virus latency. J Virol 63: 759-768.

Lillycrop KA, Dent CL, Wheatley SC, Beech MN, Ninkina NN, Wood JN, Latchman DS (1991). The octamer-binding protein Oct-2 represses HSV immediate-early genes in cell lines derived from latently infectable sensory neurons. Neuron 7: 381390.

Lillycrop KA, Latchman DS (1992). Alternative splicing of the Oct-2 transcription factor RNA is differentially regulated in neuronal cells and $B$ cells and results in protein isoforms with opposite effects on the activity of octamer/TAATGARAT-containing promoters. $J$ Biol Chem 267: 24960-24965.

Lindholm D, Heumann R, Meyer M, Thoenen H (1987). Interleukin-1 regulates synthesis of nerve growth factor in non-neuronal cells of rat sciatic nerve. Nature 330: 658-659.

Lindholm D, Heumann R, Hengerer B, Thoenen $H$ (1988). Interleukin 1 increases stability and transcription of mRNA encoding nerve growth factor in cultured rat fibroblasts. J Biol Chem 16348-16351.

Loewy AD, Bridgman PC, Mettenleiter TC (1991). $\beta$ galactosidase expressing recombinant pseudorabies virus for light and electron microscopic study of transneuronally labeled CNS neurons. Brain Res 555: $346-352$.

Lokensgard JR, Bloom DC, Dobson AT, Feldman LT (1994). Long-term promoter activity during herpes simplex virus latency. J Virol 68: $7148-7158$.
Lycke E, Hamark B, Johansson M, Krotochwil A, Lycke J, Svennerholm B (1988). Herpes simplex virus infection of the human sensory neuron. An electron microscopy study. Arch Virol 101: 87-104.

Mackem S, Roizman B (1982). Structural sequences of the $\alpha$ gene 4,0 and 27 promoter-regulatory sequences which confer $\alpha$ regulation on chimeric thymidine kinase genes. $J$ Virol 44: 939-949.

Maggioncalda J, Mehta A, Fraser NW, Block TM (1994). Analysis of a herpes simplex virus type 1 LAT mutant with a deletion between the putative promoter and the $5^{\prime}$ end of the 2.0 kilobase transcript. J Virol 68: $7816-7824$.

Marchand CF, Schwab ME (1986). Binding, uptake and retrograde axonal transport of herpes virus suis in sympathetic neurons. Brain Res 383: 262-270.

Margolis TP, Bloom DC, Dobson AT, Feldman LT, Stevens JG (1993). Decreased reporter gene expression during latent infection with HSV LAT promoter constructs. Virology 197: 585-592.

McGeoch DJ, Dalrymple MA, Davison AJ, Dolan A, Frame MC, McNab D, Perry LJ, Scott JE, Taylor P (1988). The complete DNA sequence of the long uniue region in the genome of herpes simplex virus type $1 . J$ Gen Virol 69: 1531-1574.

McKinnon W, Weisse CS, Reynolds CP, Bowles CA, Baum A (1989). Chronic stress, leukocyte subpopulations, and humoral response to latent viruses. Health Psychology 8: 389-402.

McKnight JLC, Kristie TM, Roizman B (1987). Binding of the virion protein mediating $\alpha$ gene induction in herpes simplex virus-infected cells to its cis site requires cellular proteins. Proc Natl Acad Sci (USA) 84: $7061-7065$.

Muller MT (1985). Binding of the herpes simplex virus immediate-early gene product ICP4 to its own transcription start site. J Virol 61: 1565-1574.

Natarajan R, Deshmane S, Valyi-Nagy T, Everett R, Fraser NW (1991). A herpes simplex virus type 1 mutant lacking the ICP0 introns reactivates with normal efficiency. J Virol 65: 5569-5573.

Neuwelt EA, Pagel MA, Geller A, Muldoon LL (1995). Gene replacement therapy in the central nervous system: Viral vector-mediated therapy of global neurodegenerative disease. Behav Brain Res 18: 1-9.

Nicosia M, Deshmane SL, Zabolotny JM, Valyi-Nagy T, Fraser NW (1993). Herpes simplex virus type 1 latency-associated transcript (LAT) promoter deletion mutants can express a 2-kilobase transcript mapping to the LAT region. I Virol 67: $7276-7283$.

Norgren RB Jr, McLean JH, Bubel HC, Wander A, Bernstein DI, Lehman MN (1992). Anterograde transport of HSV-1 and HSV-2 in the visual system. Brain Res Bull 28: $393-399$.

Norgren RB Jr, Lehman MN (1989). Retrograde transneuronal transport of Herpes simplex virus in the retina after injection in the superior colliculus, hypothalamus and optic chiasm. Brain Res 479: $374-$ 378.

O'Hare P, Goding CR, Haigh A (1988). Direct combinatorial interaction between a herpes simplex virus regulatory protein and a cellular octamerbinding factor mediates specific induction of virus immediate-early gene expression. EMBO J 7: 42314238 
O’Hare P, Goding CR (1988). Herpes simplex virus regulatory elements and the immunoglobulin octamer domain bind a common factor and are both targets for virion transactivation. Cell 52: 435-445.

Pazin GJ, Ho M, Jannetta PJ (1978). Herpes simplex reactivation after trigeminal nerve root decompression. J Infect Dis 138, 405.

Perng GC, Slanina SM, Ghiasi H, Nesburn AB, Wechsler SL (1996). A 371-nucleotide region between the herpes simplex virus type 1 (HSV-1) LAT promoter and the 2-kilobase LAT is not essential for efficient spontaneous reactivation of latent HSV-1. J Virol 70: 2014-2018.

Post LE, Roizman B (1981). A generalized technique for deletion of specific genes in large genomes: $\alpha$-gene 22 of herpes simplex virus 1 is not essential for growth. Cell 25: 227-232.

Preston CM (1979). Control of herpes simplex virus type 1 mRNA synthesis in cells infected with wild-type virus or the temperature-sensitive mutant tsK. $J$ Virol 29: $275-284$

Preston CM, Frame MC, Campbell MEM (1988). A complex formed between cell components and a herpes simplex virus structural polypeptide binds to a viral immediate early gene regulatory DNA sequence. Cell 52: 425-434.

Rabin ER, Jenson AB, Melnick JL (1968). Herpes simplex virus in mice: Electron microscopy of neural spread. Science 162: 126-127.

Read GS, Frenkel N (1983). Herpes simplex virus mutants defective in the virion shut-off of host polypeptide synthesis and exhibiting abnormal synthesis of $\alpha$ (immediate early) viral polypeptides. J Virol 46: $498-512$.

Rinaman L, Card JP, Enquist LW (1993). Spatiotemporal responses of astrocytes, ramified microglia, and brain macrophages to central neuronal infection with pseudorabies virus. J Neurosci 13: 685-702.

Rixon FJ, Addison C, McLauchlan J (1992). Assembly of enveloped tegument structures ( $\mathrm{L}$ particles) can occur independently of virion maturation in herpes simplex virus type 1-infected cells. J Gen Virol 73: 277-284.

Rock DL, Nesburn AB, Ghiasi H, Ong J, Lewis TL, Lokensgard JR, Wechsler SL (1987). Detection of latency-related viral RNAs in trigeminal ganglia of rabbits latently infected with herpes simplex virus type 1. J Virol 62: $3820-3826$.

Roizman B, Furlong D (1974). The replication of herpesviruses. In: Comprehensive virology. FraenkelConrat H, Wagner RR, (eds). Plenum Press: New York, pp 229-403.

Roizman B, Jenkins FJ (1985). Genetic engineering of novel genomes of large DNA viruses. Science 229: $1208-1214$

Roizman B, Sears AE (1993). Herpes simplex viruses and their replication. In: The human herpesviruses. Roizman B, Whitley RJ, Lopez C, (eds). Raven Press: New York, pp 11-68.

Rotto-Percelay DM, Wheeler JG, Osorio FA, Platt KB, Loewy AD (1992). Transneuronal labeling of spinal interneurons and sympathetic preganglionic neurons after pseudorabies virus injections in the rat medial gastrocnemius muscle. Brain Res 574: 291-306.
Sacks WR, Schaffer PA (1987). Deletion mutants in the gene encoding the herpes simplex virus type 1 immediate-early protein ICP0 exhibit impaired growth in cell culture. J Virol 61: 829-839.

Sawtell NM, Thompson RL (1992). Rapid in vivo reactivation of herpes simplex virus in latently infected murine ganglionic neurons after transient hyperthermia. J Virol 66: 2150-2156.

Schramm LP, Strack AM, Platt KB, Loewy AD (1993). Peripheral and central pathways regulating the kidney: a study using pseudorabies virus. Brain Res 616: $251-262$.

Segal AL, Katcher AH, Bringtman VJ, Miller MF (1974). Recurrent herpes labialis, recurrent apthous ulcers and the menstrual cycles. J Dent Res 53: 797.

Simmons A, Slobedman B, Speck P, Arthur J, Efstathiou $S$ (1992). Two patterns of persistence of herpes simplex virus DNA sequences in the nervous systems of latently infected mice. J Gen Virol 73: $1287-1291$

Singh H, Sen R, Baltimore D, Sharp PA (1986). A nuclear factor that binds to a conserved sequence motif in transcriptional control elements of immunoglobulin genes. Nature 319: 154-158.

Smith RL, Pizer LI, Johnson EM Jr, Wilcox CL (1992). Activation of second-messenger pathways reactivates latent herpes simplex virus in neuronal cultures. Virology 188: $311-318$.

Soffer D, Martin JR (1988). Remyelination of central nervous system lesions in experimental genital herpes simplex virus infection. J Neurol Sci 86: 83-95.

Speck PG, Simmons A (1992). Synchronous appearance of antigen-positive and latently infected neurons in spinal ganglia of mice infected with a virulent strain of herpes simplex virus. J Gen Virol 73: 1281-1285.

Spencer SE, Sawyer WB, Wada H, Platt KB, Loewy AD (1990). CNS projections to the pterygopalatine parasympathetic preganglionic neurons in the rat: a retrograde transneuronal viral cell body labeling study. Brain Res 534: 149-169.

Spruance SL (1985). Pathogenesis of herpes simplex labialis: experimental induction of lesions with UV light. J Clin Microbiol 22: 366-368.

Staudt LM, Singh H, Sen R, Wirth T, Sharp PA, Baltimore D (1986). A lymphoid-specific protein binding to the octamer motif of immunoglobulin genes. Nature 323: 640-643.

Steiner I, Spivack JG, Lirrete RP, Brown SM, MacLean AR, Subak-Sharpe J, Fraser NW (1989). Herpes simplex virus type 1 latency-associated transcripts are evidently not essential for latent infection. EMBO J 8: $505-511$.

Stevens JG, Wagner EK, Devi-Rao GB, Cook ML, Feldman LT (1987). RNA complementary to a herpesvirus alpha gene mRNA is prominent in latently infected neurons. Science 235: 1056-1059.

Stevens JG, Haarr L, Porter DD, Cook ML, Wagner EK (1988). Prominence of the herpes simplex virus latency-associated transcript in trigeminal ganglia from seropositive humans. J Infect Dis 158: 117-123. 
Stow ND, Stow EC (1986). Isolation and characterization of a herpes simplex virus type 1 mutant containing a deletion within the gene encoding the immediate early polypeptide Vmw110. J Gen Virol 67: 25712585.

Strack AM, Sawyer WB, Hughes JH, Platt KB, Loewy AD (1989). A general pattern of CNS innervation of the sympathetic outflow demonstrated by transneuronal pseudorabies viral infections. Brain Res 491: 156162.

Strack AM, Loewy AD (1990). Pseudorabies virus: a highly specific transneuronal cell body marker in the sympathetic nervous system. J Neurosci 10: 21392147.

Tanaka S, Minagawa H, Toh Y, Liu Y, Mori R (1994). Analysis by RNA-PCR of latency and reactivation of herpes simplex virus in multiple neuronal tissues. $J$ Gen Virol 75: 2691-2698.

Tenser RB, Edris WA (1987). Trigeminal ganglion infection by thymidine kinase-negative mutants of herpes simplex virus after in vivo complementation. $J$ Virol 61: 2171-2174.

Townsend JJ (1981a). The demyelinating effect of corneal HSV infections in normal and nude (athymic) mice. $J$ Neurol Sci 50: 435-441.

Townsend JJ (1981b). The relationship of astrocytes and macrophages to CNS demyelination after experimental herpes simplex virus infection. J Neuropath Exp Neurol 40: $369-379$.

Townsend JJ (1983). Schwann cell remyelination in experimental herpes simplex encephalitis at the trigeminal root entry zone. J Neuropath Exp Neurol 42: $529-538$.

Townsend JJ, Baringer JR (1978a). Central nervous system susceptibility to herpes simplex infection. $J$ Neuropath Exp Neurol 37: 255-262.

Townsend JJ, Baringer JR (1978b). Alteration of herpes simplex virus induced CNS lesions by immunosuppression. J Neuropathol Exp Neurol 37: $701-710$

Townsend JJ, Collins PK (1986). Peripheral nervous system demyelination with herpes simplex virus. $J$ Neuropath Exp Neurol 45: 419-425.

Ugolini G, Kuypers HG, Simmons A (1987). Retrograde transneuronal transfer of herpes simplex virus type 1 (HSV 1) from motoneurones. Brain Res 422: 242-256.

Vahlne A, Nystrom B, Sandberg M, Hamberger A, Lycke E (1978). Attachment of herpes simplex virus to neurons and glial cells. J Gen Virol 40: 359-371.

Vahlne A, Svennerholm B, Sandberg M, Hamberger A, Lycke E (1980). Differences in attachment between herpes simplex type 1 and type 2 viruses to neurons and glial cells. Infect Immun 28: 675-680.

Vahlne A, Edstrom S, Hanner P, Andersen O, Svennerholm B, Lycke E (1985). Possible association of herpes simplex virus infection with demyelinating disease. Scand J Infect Dis - Supplementum 47: 16-21.

Vahlne A, Lycke E (1978). Herpes simplex virus infection of in vitro cultured neuronal cells (Mouse neuroblastoma C 1300 cells). J Gen Virol 39: $321-$ 332

Vizzard MA, Erickson VL, Card JP, Roppolo JR, de Groat WC (1995). Transneuronal labeling of neurons in the adult rat brainstem and spinal cord after injection of pseudorabies virus into the urethra. J Comp Neurol 355: $629-640$.
Wagner EK, Flanagan WM, Devi-Rao G, Zhang YF, Hill JM, Anderson KP, Stevens JG (1988). The herpes simplex virus latency-associated transcript is spliced during the latent phase of infection. J Virol 62: 45774585 .

Ward PL, Roizman B (1994). Herpes simplex genes: the blueprint of a successful human pathogen. Trends Genet 10: $267-274$.

Watson RJ, Clements JB (1980). A herpes simplex virus type 1 function continuously required for early and late virus RNA synthesis. Nature 285: 329-330.

Wechsler SL, Nesburn AB, Watson R, Slanina S, Ghiasi $H$ (1988). Fine mapping of the major latency-related RNA of herpes simplex virus type 1 in humans. $J$ Gen Virol 69: $3101-3106$.

Werstuck G, Bilan P, Capone JP (1990). Enhanced infectivity of herpes simplex virus type 1 viral DNA in a cell line expressing the trans-inducing factor Vmw65. J Virol 64: 984-991.

Wheatley SC, Kemp LM, Wood JN, Latchman DS (1990). Cell lines derived from dorsal root ganglion neurons are nonpermissive for HSV and express only the latency-associated transcript following infection. Exp Cell Res 190: $243-246$.

Whitley RJ, Gnann JWJ (1993). The epidemiology and clinical manifestations of herpes simplex virus infections. In: The human herpesviruses. Roizman B, Whitley RJ, Lopez C, (eds). Raven Press: New York, pp 69-106.

Wilcox CL, Smith RL, Freed CR, Johnson EM Jr (1990). Nerve growth factor-dependence of herpes simplex virus latency in peripheral sympathetic and sensory neurons in vitro. J Neurosci 10: 1268-1275.

Wilcox CL, Johnson EM Jr (1987). Nerve growth factor deprivation results in the reactivation of latent herpes simplex virus in vitro. J Virol 61: 2311-2315.

Wilcox C, Johnson EJ (1988). Characterization of nerve growth factor-dependent herpes simplex virus latency in neurons in vitro. J Virol 62: 393-399.

Wirth T, Priess A, Annweiler A, Zwilling S, Oeler B (1991). Multiple Oct2 isoforms are generated by alternative splicing. Nucl Acids Res 19: 43-51.

Wolfe JH, Deshmane SL, Fraser NW (1992). Herpes virus vector gene transfer and expression of $\beta$ glucouronidase in the central nervous system of MPS VII mice. Nat Genet 1: 379-384.

Wood JN, Lillycrop KA, Dent CL, Ninkina NN, Beech MM, Willoughby JJ, Winter J, Latchman DS (1992). Regulation of expression of the neuronal POU protein oct-2 by nerve growth factor. $J$ Biol Chem 267: $17787-17791$.

Zemanick MC, Strick PL, Dix RD (1991). Direction of transneuronal transport of herpes simplex virus 1 in the primate motor system is strain-dependent. Proc Natl Acad Sci (USA) 88: 8048-8051.

Zhao M, Azumi A, Atherton SS (1995). T lymphocyte infiltration in the brain following anterior chamber inoculation of HSV-1. J Neuroimmuno 58: 11-19. 